www.jmscr.igmpublication.org

Impact Factor 5.244

Index Copernicus Value: 83.27

ISSN (e)-2347-176x ISSN (p) 2455-0450

crossref DOI:_http://dx.doi.org/10.18535/jmscr/v4i9.40

Journal Of Medical Science And Clinical Research

\title{
Intraperitoneal Hydrocortisone plus Bupivacaine Administration for Pain Relief after Laparoscopic Cholecystectomy, a Comparison with Bupivacaine Alone
}

Authors

\author{
Ashvin R Kankotiya ${ }^{1}$, Digant Patel $^{2}$ \\ ${ }^{1,2}$ M.S. (General Surgeon), Dept of surgery, Government Medical College Baroda, Vadodara, India \\ Corresponding Author \\ Ashvin R. Kankotiya \\ Address: 50, Balwant Nagar Soc., Near Dhanmora Complex, Katargam, Surat Pin-395004 \\ Email: drashvin31@yahoo.com, Contact no.: 9925775191
}

\begin{abstract}
Background: Laparoscopic Cholecystectomy $(L C)$ has become the gold standard for treatment of benign Gall Bladder disease. Laparoscopy provides many benefits over conventional open procedures including faster recovery time, shorter hospital stay, less pain, and in some cases, fewer complications. Post Operative pain management has an important role in preventing the postoperative morbidity and its consequences. This study is designed to evaluate the effect of intraperitoneal instillation of bupivacaine with hydrocortisone in comparison to bupivacaine alone for pain relief following laparoscopic Cholecystectomy.

Aim and Objectives: To compare the effect of intraperitoneal instillation of bupivacaine with Hydrocortisone versus Bupivacaine alone for post-operative analgesia in laparoscopic Cholecystectomy.

Methods: This study includes Laparoscopic Cholecystectomy conducted in the department of General Surgery at the Sir Sayajirao General Hospital \& Medical College Baroda during a period of 12 months from January 2015 to December 2015. The patients were randomized into two groups by envelop method. Assessment of the pain was done \& its intensity was recorded on VAS (visual Analogue scale) after Ohrs, 6 hrs, $12 \mathrm{hrs} \& 24 \mathrm{hrs}$ of surgery.

Results: Total 50 patients were studied. Each group contain 25 patients. Bupivacaine with hydrocortisone instillation shows significant reduction in VAS Score at $6 \mathrm{hr}, 12 \mathrm{hr}$ and $24 \mathrm{hr}(2.40,3.28$ and 4.00) as compare to bupivacaine alone (3.24,4.28 and 5.04) and it is statistically significant as $p$ value is $<0.05$ (0.0039,0.0026 and 0.0046) While reduction in VAS Score at o hr (1.08 and 1.48) is not statistically significant as $p$ value is $>0.05$ (0.3950).

Conclusion: Intraperitoneal preoperative pre-emptive instillation of hydrocortisone with bupivacaine in laparoscopic Cholecystectomy significantly reduce post operative pain at $6 \mathrm{hr}, 12 \mathrm{hr}$ and $24 \mathrm{hr}$ but not at $0 \mathrm{hr}$, in comparison to bupivacaine alone.

Keywords: Laparoscopic Cholecystectomy (LC), Visual Analogue scale (VAS).
\end{abstract}

\section{INTRODUCTION}

With the expanding role of ambulatory surgery and the need to facilitate an earlier hospital

discharge, improving postoperative pain control has become an increasingly important issue. ${ }^{1}$ 
Laparoscopic Cholecystectomy (LC) has become the gold standard for treatment of benign Gall Bladder disease. Laparoscopy provides many benefits over conventional open procedures including faster recovery time, shorter hospital stay, less pain, and in some cases, fewer complications. Despite minimal invasive nature of laparoscopic surgery, pain may be substantial and limit an otherwise expeditious recovery.

Adequacy of postoperative pain control is one of the most important factors in determining when a patient can be safely discharged from surgical facility and has a major influence on the patient's ability to resume their normal activities of daily living. ${ }^{2}$

Analgesia provided before a noxious stimulus, known as pre emptive analgesia, may prevent physiologic changes, resulting in central sensitization and amplification of pain signals. Pre-emptive local anaesthesia, therefore, may be more effective than postoperative anaesthesia administration at preventing postoperative pain.

Many experimental and clinical studies have demonstrated the inhibitory effect of pre-emptive analgesia on the development posttraumatic hyperalgesia, resulting in reduced post operative pain and total analgesic requirements. ${ }^{3-10}$ Bupivacaine $(0.5 \%)$ is the most consistently used local anaesthetic in pre-emptive analgesia.

\section{PATIENTS AND METHODS}

A prospective, randomized study of 50 patients of laparoscopic Cholecystectomy (LC) was conducted in the department of General Surgery at the Sir Sayajirao General Hospital \& Medical College Baroda during a period of 12 months from January 2015 to December 2015.

All adult patients of ASA-1 and 2 in the age group of 18 to 60 years irrespective of sex scheduled for Elective laparoscopic Cholecystectomy were included in the study. Patients in whom conversion to open Cholecystectomy, ASA grade III and IV, History of taking opioids, tranquilizer, steroids or NSAIDS were excluded from the study.
After taking informed and written consent, patients were randomized in two groups using enveloped method. On the day of surgery an independent hospital staff randomly opened an envelope with a card in side. Patients were randomized to their respective card group, either 'A', or 'B'

GROUP 'A': In which $100 \mathrm{mg}$ bupivacaine in 250 $\mathrm{ml}$ of normal saline was instilled in peritoneal cavity.

GROUP 'B': In which $100 \mathrm{mg}$ hydrocortisone and $100 \mathrm{mg}$ bupivacaine in $250 \mathrm{ml}$ of normal saline was instilled in peritoneal cavity.

After installation of drugs patient was rotated into Trendelenburg, anti-Trendelenburg, left and right lateral decubitus and finally supine positions (each for 2 minutes).

Patients will be followed by a blind investigator for postoperative abdominal pain using VAS based on a $0-10$ scale(with 0 meaning no pain and 10 meaning the most intense pain ever experienced) in the recovery room and at 6,12 and 24 hours after operation.

\section{STATISTICAL METHODS}

Statistical analysis was done by SPSS 17.0 software. Chi-square $\left(\mathrm{X}^{2}\right)$ test, unpaired t test and Mann-Whitney test was used for analysis of data. The p-value for significance level was set at 0.05.

\section{RESULTS}

A prospective, randomized study of 50 patients of' INTRAPERITONEAL HYDROCORTISONE PLUS BUPIVACAINE ADMINISTRATION FOR PAIN RELIEF AFTER LAPAROSCOPIC CHOLECYSTECTOMY, A COMPARISON WITH BUPIVACAINE "was conducted.

Patients were randomized in two groups:

In Bupivacaine group (group A) total patients: 25. In Bupivacaine plus Hydrocortisone group (group

B) total patients: 25 . 


\section{JMSCR Vol||04||Issue||09||Page 12551-12557||September}

Table1: Distribution of patients according to age.

\begin{tabular}{|l|l|l|l|}
\hline AGE GROUP & GROUP A & GROUP B & TOTAL \\
\hline $\mathbf{1 8}$ to 30 & 6 & 7 & 13 \\
\hline $\mathbf{3 1}$ to 40 & 10 & 11 & 21 \\
\hline $\mathbf{4 1}$ to 50 & 5 & 3 & 08 \\
\hline 51 to 60 & 4 & 4 & 08 \\
\hline
\end{tabular}

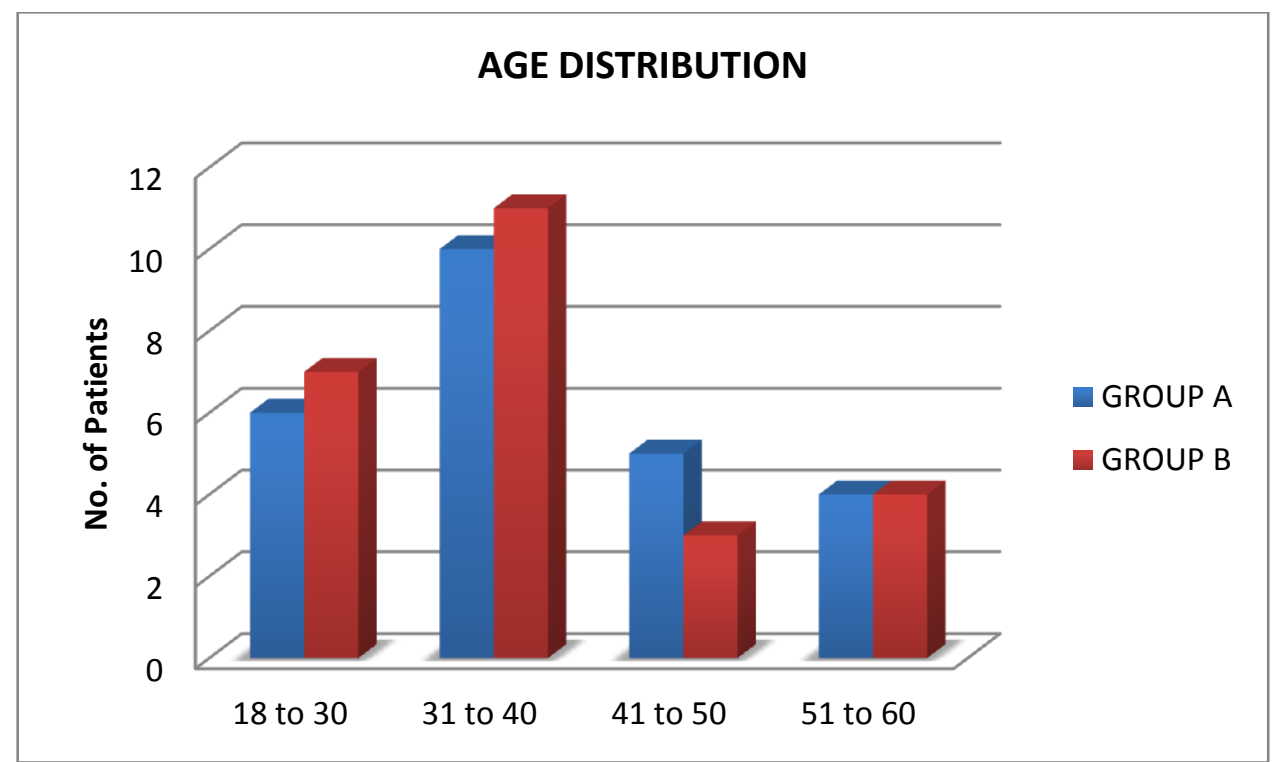

Table 2 : Comparisons Between Two Groups Vas At 0 Hrs

\begin{tabular}{|l|l|l|}
\hline VAS Score & Group A & Group B \\
\hline 0 to 3 & 23 & 24 \\
\hline $\mathbf{4}$ to 7 & 2 & 1 \\
\hline 8 to 10 & 0 & 0 \\
\hline
\end{tabular}

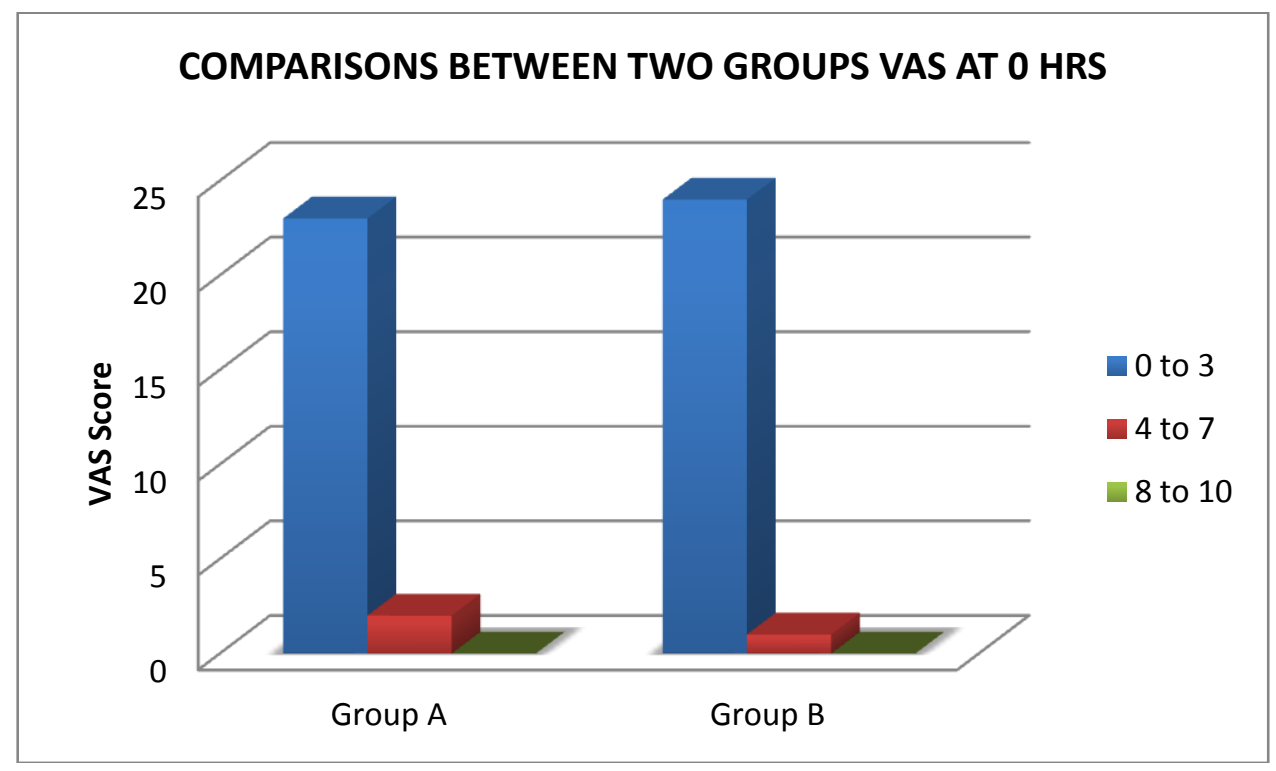

Comparisons Between Two Groups Vas At 0 Hrs

\begin{tabular}{|l|l|}
\hline & Group A \& B AT 0HRS \\
\hline Mann - Whitney U value & 270.50 \\
\hline 'p' value & 0.3950 \\
\hline Significance ('p'value $<0.05)$ & Not Significant \\
\hline
\end{tabular}


Table 3: Comparisons Between Two Groups Vas At 6 Hrs

\begin{tabular}{|l|l|l|}
\hline Vas Score & Group A & Group B \\
\hline 0 to 3 & 18 & 22 \\
\hline 4 to 7 & 7 & 3 \\
\hline 8 to 10 & 0 & 0 \\
\hline
\end{tabular}

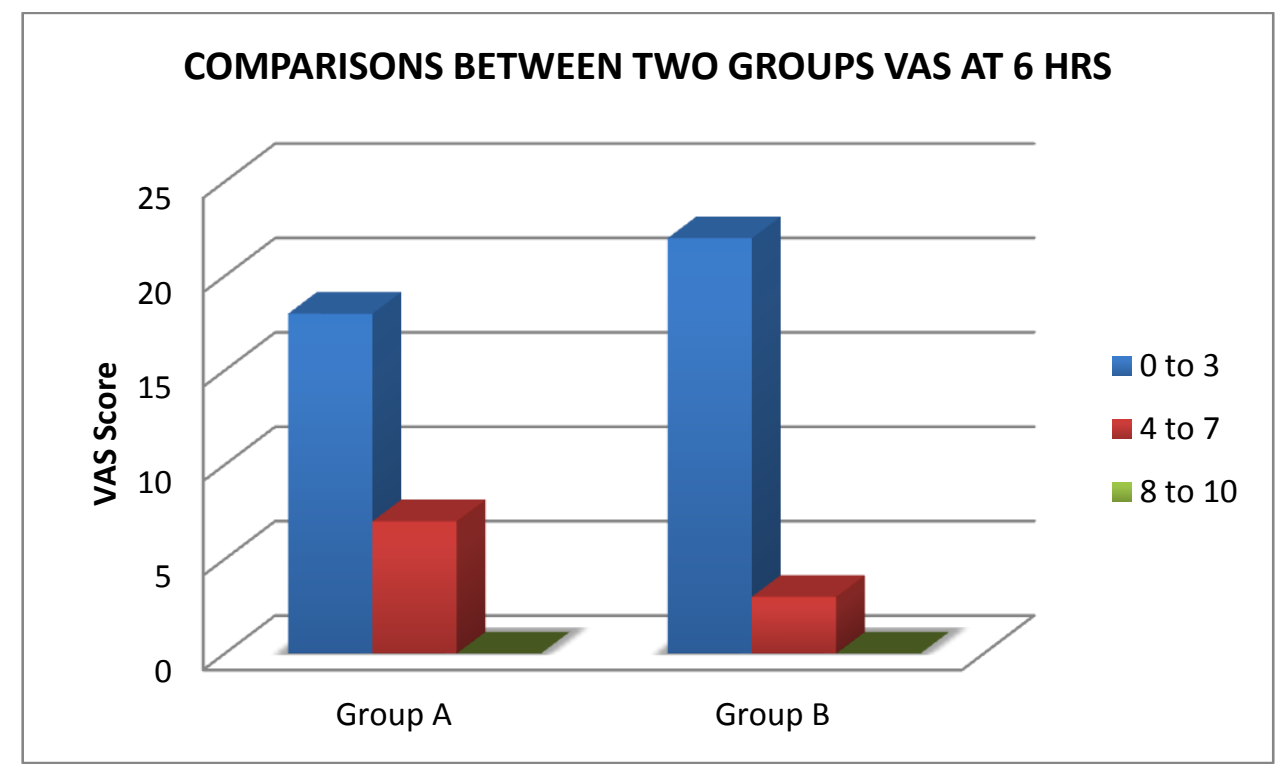

Comparisons Between Two Groups For Vas 6 Hrs

\begin{tabular}{|l|l|}
\hline & Group A \& B AT 6 HRS \\
\hline Mann - Whitney U value & 210.0 \\
\hline 'p' value & 0.039 \\
\hline Significance ('p'value $<0.05$ ) & Significant \\
\hline
\end{tabular}

Table 4: Comparisons Between Two Groups Vas At 12 Hrs

\begin{tabular}{|l|l|l|}
\hline Vas Score & Group A & Group B \\
\hline 0 to 3 & 10 & 18 \\
\hline $\mathbf{4}$ to 7 & 14 & 6 \\
\hline 8 to 10 & 1 & 1 \\
\hline
\end{tabular}

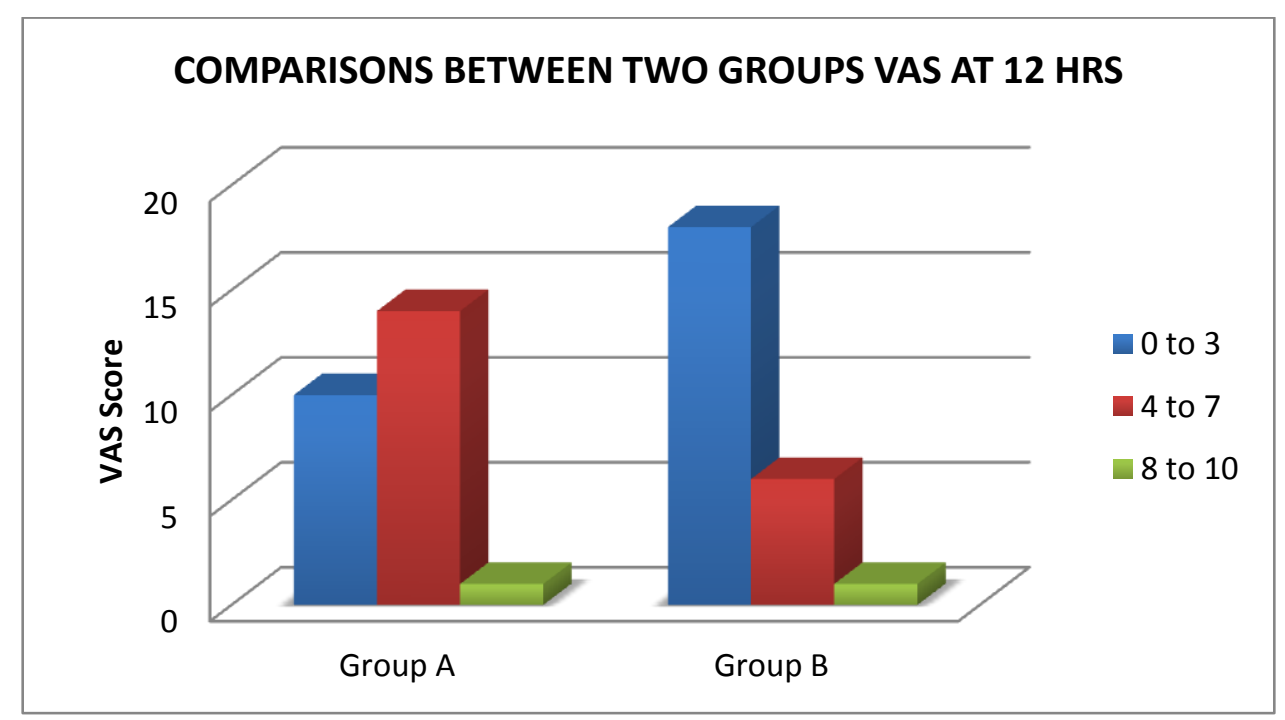

Comparisons Between Two Groups For Vas 12 Hrs

\begin{tabular}{|l|l|}
\hline & Group A \& B AT 12 HRS \\
\hline Mann - Whitney U value & 199.50 \\
\hline 'p' value & 0.026 \\
\hline Significance ('p'value $<0.05)$ & Significant \\
\hline
\end{tabular}


Table 5: Comparisons Between Two Groups Vas At 24 Hrs

\begin{tabular}{|l|l|l|}
\hline Vas Score & Group A & Group B \\
\hline 0 to 3 & 6 & 15 \\
\hline 4 to 7 & 17 & 8 \\
\hline 8 to 10 & 2 & 2 \\
\hline
\end{tabular}

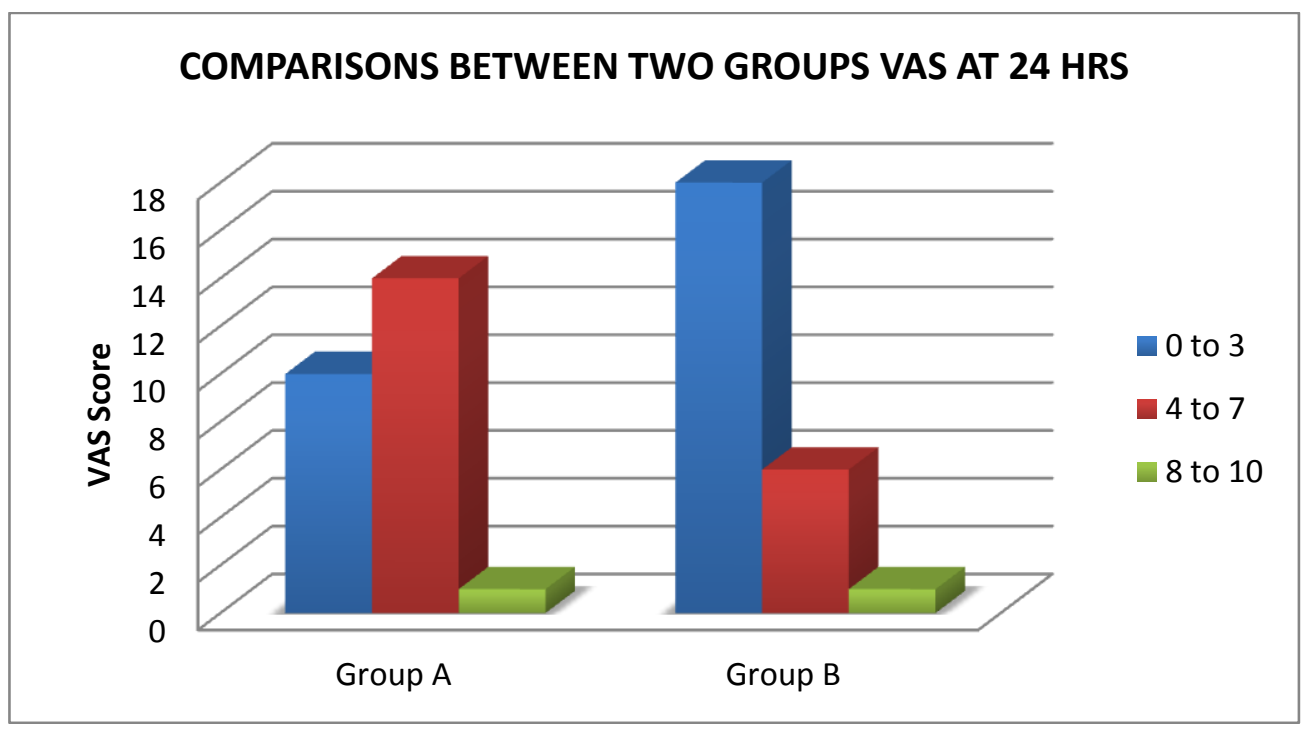

Comparisons Between Two Groups For Vas 24 Hrs

\begin{tabular}{|l|l|}
\hline & Group A \& B AT 24 HRS \\
\hline Mann - Whitney U value & 211.0 \\
\hline 'p' value & 0.046 \\
\hline Significance ('p'value $<0.05$ ) & Significant \\
\hline
\end{tabular}

On comparing study Group A with study Group B for post-operative VAS value which was less in GROUP B.

'p' value was highly significant $(\mathrm{p}<0.05)$ at $6 \mathrm{hrs}, 12 \mathrm{hrs}$ and $24 \mathrm{hrs}$ VAS Score. There was no significant difference in VAS Score in group A and group B at 0 hrs.

Table 6: Table Statistical Analysis Of Vas By Mann Whitney U Test Regarding Vas Value

\begin{tabular}{|l|l|l|}
\hline VAS Score & GROUP & VAS \\
\hline \multirow{3}{*}{$0 \mathrm{hrs}$} & $\mathrm{A}$ & 1.48 \\
\cline { 2 - 3 } & $\mathrm{B}$ & 1.08 \\
\hline \multirow{3}{*}{$6 \mathrm{hrs}$} & $\mathrm{A}$ & 3.24 \\
\cline { 2 - 3 } & $\mathrm{B}$ & 2.40 \\
\hline \multirow{3}{*}{$12 \mathrm{hrs}$} & $\mathrm{A}$ & 4.28 \\
\cline { 2 - 3 } & $\mathrm{B}$ & 3.28 \\
\hline \multirow{2}{*}{$24 \mathrm{hrs}$} & $\mathrm{A}$ & 5.04 \\
\cline { 2 - 3 } & $\mathrm{B}$ & 4.00 \\
\hline
\end{tabular}

On comparison by Mann Whitney U Test between Group A and B, data shown for pain that the VAS value was less at all assessment as compared to Group A.

\section{DISCUSSION}

Laparoscopic Cholecystectomy results in less post operative pain and/or reduced analgesic consumption as compared with open Cholecystectomy. Still some patients of LC experience considerable discomfort during first 24 postoperative hours.

There are many methods of analgesia with varying rates of success to diminish the intensity of postoperative pain after laparoscopic Cholecystectomy. 
These include:

- Low-pressure pneumoperitoneum,

- Local Anaesthetic (LA) infiltration at trocar site, ${ }^{3,6,7,8}$

- Instillation of the sub-diaphragmatic region with a local anaesthetic, usually using Bupivacaine, ${ }^{3-7}$

- Use of conventional opioids and non opioids analgesics in the postoperative period.

Bupivacaine a local anaesthetic agent used in present study for intraperitoneal instillation for post operative pain relief after removal of gall bladder because it is most commonly used in most of previous studies for pre-emptive analgesia. ${ }^{3}$
The peak serum level of intraperitoneal Bupivacaine is reached 20 to $30 \mathrm{~min}$ after application and lasts for 2 to 24 hours after surgery because the half life of Bupivacaine is 1.5 -5.5 hours.

Hydrocortisone is added to bupivacaine for this study to improve the pain control. It has been shown that glucocorticoids can play a crucial role in the regulation of inflammatory response through both genomic and nongenomic mechanisms and therefore may reduce pain. ${ }^{11}$ prolonging the onset and duration of nerve blockade that can reduce their effective dosage and side effects by addition glucocorticoid to local anaesthetics showed in different studies. ${ }^{12,13}$

Table 7: Comparison Of Different Study And Present Study For Demographic Data

\begin{tabular}{|l|l|l|l|l|}
\hline Study & Sample Size & Sex ratio M/F & Mean age & Comparison \\
\hline Maestroni et al 2002 & 60 & $23 / 37$ & $54.9 \pm 15$ & Intraperitoneal bupivacaine Vs Placebo \\
\hline Sabzi Sarvestani 2014 & 60 & $24 / 36$ & $44.16 \pm 8.31$ & $\begin{array}{l}\text { Intraperitoneal bupivacaine Vs Intraperitoneal } \\
\text { bupivacaine plus hydrocortisone }\end{array}$ \\
\hline Mehdi Mohemmadi & 62 & $23 / 37$ & $44.3 \pm 3.16$ & Intraperitoneal hydrocortisone Vs placebo \\
\hline Present Study & 50 & $15 / 35$ & $38.7 \pm 16.5$ & $\begin{array}{l}\text { Intraperitoneal bupivacaine Vs Intraperitoneal } \\
\text { bupivacaine plus hydrocortisone }\end{array}$ \\
\hline
\end{tabular}

Table 8: Comparison Of Mean Vas Score In Different Study

\begin{tabular}{|l|c|c|c|}
\hline Vas Score & $\begin{array}{c}\text { Sabzi Sarvestani } 2014 \\
\text { (P value) }\end{array}$ & $\begin{array}{c}\text { Mehdi Mohemmdi } \\
\text { (P value) }\end{array}$ & $\begin{array}{c}\text { Present study } \\
\text { (P value) }\end{array}$ \\
\hline $0 \mathrm{hr}$ & 0.001 & 0.025 & 0.3950 \\
\hline $6 \mathrm{hr}$ & 0.001 & 0.007 & 0.039 \\
\hline $12 \mathrm{hr}$ & 0.001 & 0.006 & 0.026 \\
\hline $24 \mathrm{hr}$ & 0.004 & 0.012 & 0.046 \\
\hline
\end{tabular}

Comparison of present study with Sabzi Sarvestani and Mehdi Mohemmdi shows that the $\mathrm{p}$ value of VAS Score at $0 \mathrm{hr}$ is not significant as in both study. While $\mathrm{p}$ value at $6 \mathrm{hr}, 12 \mathrm{hr}$ and $24 \mathrm{hrs}$ are statistically significant as in both study. Significant difference in VAS score can be explained by action of glucocorticoids which prolong the onset and duration of nerve blockade by local anaesthetics.

Limitations with this study are that, We did not adopted saline (placebo) controlled design, which would have raised more questions. Although all surgeries followed a strict protocol, the patients were operated by a number of surgeons with varying experiences; hence minor variations in surgical technique and tissue handling may have been there. Though the patients were properly educated about VAS, some illiterate patients could not be adequately understood the instruction and accordingly in certain instances they may not have revealed their pain appropriately.

\section{CONCLUSION}

This study suggest that intraperitoneal preoperative pre-emptive instillation of hydrocortisone with bupivacaine in laparoscopic Cholecystectomy significantly reduce post operative pain at $6 \mathrm{hr}, 12 \mathrm{hrs}$ and $24 \mathrm{hrs}$ in comparison to bupivacaine alone. While the reduction in pain at $0 \mathrm{hr}$ is not significant. 


\section{ACKNOWLEDGEMENT}

This study has only been possible as a result of the help; we have received from so many people. We are thanking to our head of department Dr. D.D.Duttaroy, our head of the unit Dr.Nimish Shah, my guide Dr.Adeesh jain, my colleagues Dr. Jitendra, Dr.burhan, and juniors. We are also thank full to all patients who had given consent to be a part of this study. In addition, there are many un-named colleagues whom we wish to thank. We would like to thank our immediate families for all their support during whole period.

\section{REFERENCES}

1. Paul FW. The changing role of nonopioid analgesic techniques in the management of postoperative pain. Anesth Analg 2005;101: 5-22.

2. Kehlet H, Dahl JB. Anesthesia, surgery and challenges in postoperative recovery. Lancet 2003;362: 1921-8.

3. Barczynski M, Konturek A, Herman RM, Superiority of pre-emptive analgesia with intraperitoneal instillation of Bupivacaine before rather than after the creation of pneumoperitoneum for laparoscopic Cholecystectomy: a randomized, doubleblind, placebo-controlled study. Surg Endosc 2005; 20: 1088-1093.

4. Maestroni U, Sortini, Devito C, Pour Morad Kohan Brunaldi F, Anania G, Pavanelli L, Pasqualucci A, Donini AA new method of pre-emptive analgesia in laparoscopic Cholecystectomy: a randomized, double-blind, placebocontrolled study. Surg Endosc 2OO2; 16: 1336-1340.

5. Pascqualucci A, Angelis DV, Contardo R, Colo F, Terrosu G, Donini A, Pasetto A, Bresadola F, Pre-emptive analgesia: A randomized, double-blind, placebocontrolled study. Anesthesiology 1996; 85: 11-20.

6. Coughlin SM, Karanicolas PJ, Heather MA, Bilge Kanbur, Savas Kanbur,
Colquhoun PHD. Better late than never? Impact of local analgesia timing on postoperative pain in laparoscopic surgery: a systemic review and meta analysis. Surg Endosc 2010; 24: 3167-3176.

7. Lee IO, Kim SH, Kong MH, Lee MK, Kim NS, Choi YS, Lim SH. Pain after laparoscopic Cholecystectomy: the effect and timing of incisional and intraperitoneal Bupivacaine. Can J Anaesth 2001; 48:545-550.

8. Mixter CG, Hackett TR. Pre-emptive analgesia in the laparoscopic patient. Surg Endosc 1997; 11:351-353.

9. Moiniche S, Jorgensen $\mathrm{H}$, Wetterslev J, and Dahl JB. Local Anaesthetic Infiltration for Postoperative Pain Relief after Laparoscopy. Anesth Analg 2000; 90:899912.

10. Kahokehr A, Sammour T, Soop M, Hill AG. Intraperitoneal use of local anaesthetic laparoscopic Cholecystectomy: systematic review and meta

11. Stahn C, Buttgereit F. genomic and nongemomic effect of glucocorticoids. Nat Clin Pract Rheumatol. 2008 oct;4(10):525-33.

12. Mirzai H, Tekin I, Alincak H. Perioperative use of corticosteroid and bupivacaine combination in lumbar disc surgery;a randomized controlled trial. Spine(Phila pa 1976).2002;27(4):343-6.

13. Stan T, Goodman EJ, Holbrook CR. Adding methylprednisolone to local anesthetic increase the duration of axillary block. Reg Anesth Pain Med. 2004; 29(4);380-1.

\section{LIST OF ABBREVEATIONS}

LC: Laparoscopic Cholecystectomy

ASA: American society of anaesthesiologists SPSS: Statistical presenting system software VAS: Visual analogue scale 